\title{
Culturing Puccinia coronata on a Cell Monolayer of the Avena sativa Coleoptile
}

\author{
By \\ K. Mendgen and Elvira Dressler
}

With 12 figures

Received August 26, 1983

\begin{abstract}
A culture of Puccinia coronata on an epidermal cell monolayer dissected from the Avena sativa coleoptile is described. To induce fungal development, infection structure formation had to be induced with a heat treatment. The host cells were fed with $1 \%$ sucrose (or glucose or manitol) to sustain fungal growth. Under these conditions, normal development of hyphae, haustoria with haustorial mother cells and uredospores occurred. Uredospores had normal infectivity.
\end{abstract}

\section{Zusammenfassung}

Die Kultur von Puccinia coronata auf einer Zellschicht der Avena Koleoptile

Der Haferkronenrost (Puccinia coronata) läßt sich auf einer Epidermiszellschicht, die aus Haferkoleoptilen herauspräpariert wurde, gut kultivieren. Voraussetzung war jedoch, daß mit einem Hitzeschock die Infektionsstrukturen (Appressorium, substomatäres Vesikel und Infektionshyphe) induziert wurden und daß die Zellen mit Zuckern (Saccharose, Glucose oder Mannit) gefüttert wurden. Der Rostpilze differenzierte normale Haustorien und Uredosporen mit normaler Morphologie und Infektiosität aus.

Since the first rust culture experiments using Gymnosporangium juniperivirginianae (Hotson and CUTTER 1951) and Puccinia graminis f. sp. tritici (Williams et al. 1966), many rust fungi can now be grown in axenic culture (see Maclean 1982, Williams 1984). After seeding uredospores on agar, infection structures, hyphae, uredospores and teliospores were produced very often in such cultures. Haustoria, consisting of a haustorial mother cell, a haustorial neck and a haustorial body have not been described. This paper describes a system where Puccinia coronata was cultured including normal 
haustoria and uredospores on an epidermal cell layer from oat coleoptiles. The cell layer was prepared according to Bushnell's method for the culture of Erysiphe graminis f.sp. hordei on barley coleoptiles (BusHnell et al. 1967). A short report of this new type of rust culture has been published earlier (MENDGEN 1982).

\section{Material and Methods}

\section{Preparation of the coleoptile cell monolayer}

A compatible host-parasite sysiem was used consisting of Puccinia coronata Cda var. avenae Fras. \& Led., race HKR 2 and Avenia sativa L. cv. Selma.

Oat was grown in a chamber illuminated with fluorescent lamps (about $6000 \mathrm{~lx}$ for $16 \mathrm{~h}$ per day) at $20^{\circ} \mathrm{C}$. After $7-8$ days, the coleoptiles were harvested and dissected to leave the inner epidermis (Bushnell et al. 1967, Takamatsu et al. 1978). The resuliting epidermal layer, kept its vascular bundles attached on both sides (Figs. 1 and 2). It was floated with the indi-

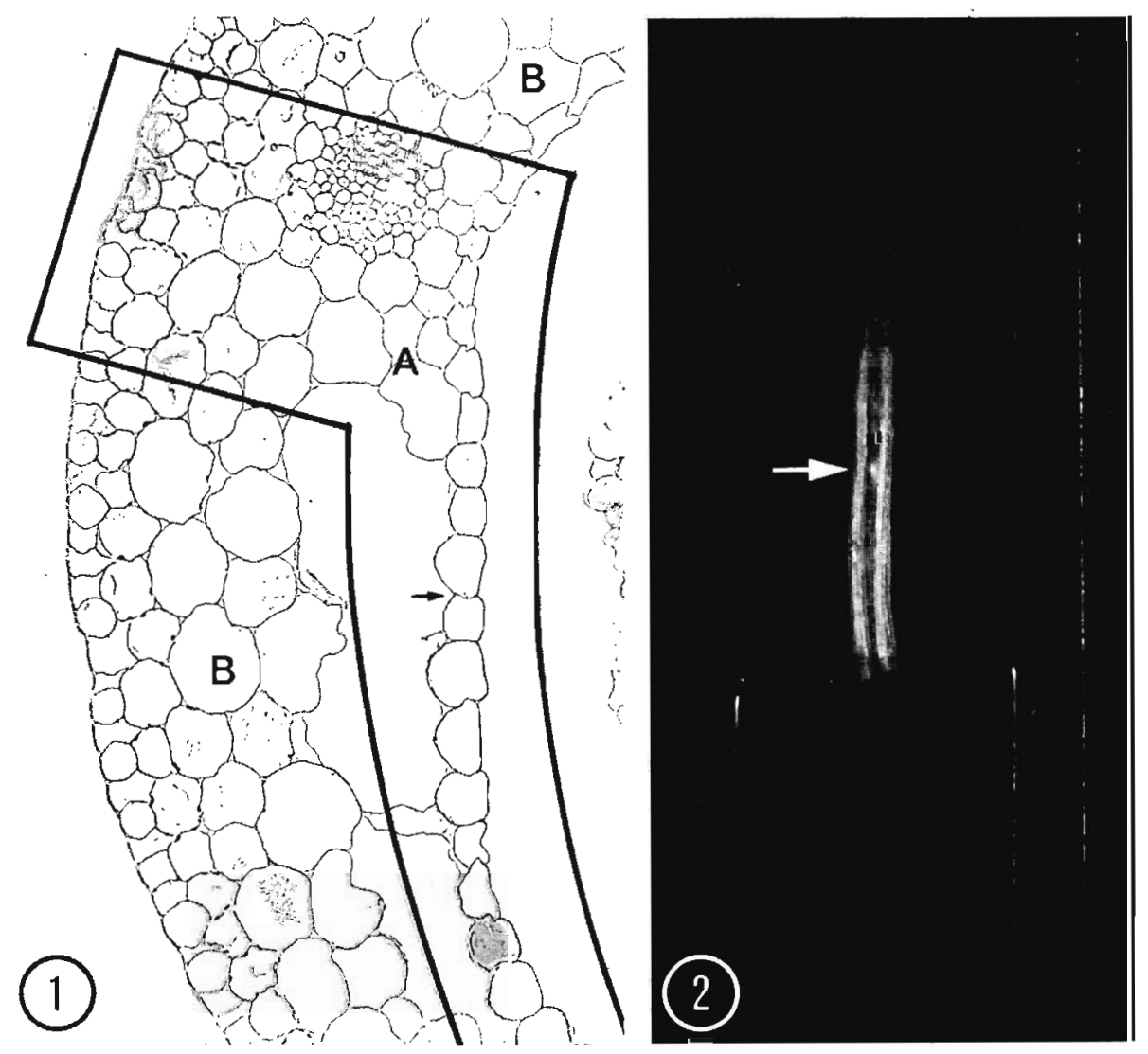

Fig. 1. Cross section of the Avena coleoptile showing a part of the dissected area: the inner epidermis with the bundle (A) and the discarded part of the coleoptile (B). The arrow shows the inner surface of the epidermis on which the spores are placed (X110). - Fig. 2. The dissected inner epidermis spread on a microscope slide. Both ends of the epidermal layer are fixed with a cover slip. The arrow indicates a very young $(\sim 3$ days $)$ rust colony $(\sim$ natural size $)$ 
cated solutions on a microscope slide. Both of the cut ends of the epidermis were covered with a cover slip. The inner cuticular surface was floated uppermost (Fig. 1) in contrast to the preparation of BushNell et al. (1967). For each experiment, 10-20 coleoptile preparations were inoculated in a settling tower with approximately $1-3$ uredospores $/ \mathrm{mm}^{2}$. After inoculation, it was very important to keep the coleoptile under saturated air humidity in an incubator, however accidential water on the inner surface of the epidermis resulted in very poor spore germination. Most experiments were performed at room temperature, $\sim 20^{\circ} \mathrm{C}$, and normal laboratory illumination. Continuous darkness had no effect on the results. Two hours after inoculation, the epidermal preparations were transferred to $30^{\circ} \mathrm{C}$ for two hours. In some experiments, this heat shock treatment was repeated $24 \mathrm{hr}$ later. The growth of the developing mycelium was followed every two days with a $\times 40$ planachromatic Zeiss lens. During observation, the whole coleoptile mount was covered with a large cover slip.

\section{Cytology}

For nuclear observations, the epidermal preparations were fixed in $1 \%$ glutaraldehyde in $0.01 \mathrm{M}$ phosphate buffer $\mathrm{pH} 7.2$, rinsed in the same buffer and stained in a solution of 4.6 diamidino-2-phenylindol $2 \mathrm{HCl}$ (Serva, Heidelberg) = DAPI, about $10 \mu \mathrm{l} / \mathrm{ml}$ buffer.

For light- and electron microscopy, epidermal preparations were fixed in $4 \%$ glutaraldehyde in phosphate buffer $0.01 \mathrm{M} \mathrm{pH} 7.8$ for 8 hours, postfixed in $2 \%$ osmic acid for 8 hours, dehydrated in alcohol and embedded in Spurr's medium. Sections were made with a Reichert Ultrotome and viewed in a Reichert Univar microscope or, after uranylacetate and lead staining, in a Zeiss EM 10 CR electron microscope.

For scanning electronmicroscopy (SEM), the samples were flushed with argon for a few seconds and plunged into liquid nitrogen slush. The samples were then kept under vacuum and sputter coated with gold-palladium during 4 minutes in the $\mathrm{Sp} 2000$ Sputter cyro (Emscope) at $-176^{\circ} \mathrm{C}$. They were then transferred into the Cambridge Stereoscan $250 \mathrm{Mk} 2$ and observed at $-160^{\circ} \mathrm{C}$ with an accelerating voltage of $10 \mathrm{KV}$ (Figs. 3, 4 and 7). Figures 5 and 6 were made with a Jeol JSM - 35 CF SEM and the samples were prepared with the Hexland-Polaron Cryotrans system.

\section{Results}

\section{The influence of heat shock and sugar nutrition on the pustule development}

Without the heat treatment, germ tubes began to branch after $24 \mathrm{~h}, 1 \%$ to $4 \%$ formed vesicles, infection hyphae were seen on rare occasions $(<0.4 \%)$. About two thousend germ tubes. were examined but no haustoria were found under these conditions. All hyphae died within 8 days. The cells of the epidermal preparation were still living at that time.

After application of a heat shock $\left(30^{\circ} \mathrm{C}\right.$ for two hours) or two heat shocks $\left(30^{\circ} \mathrm{C}\right.$ for two hours and the same treatment 24 hours later), 12 to $20 \%$ of the sporelings formed infection structures consisting of an appressorium-like vesicle, a second vesicle resembling a substomatal vesicle and a typical infection hypha. Many of these infection hyphae (in most experiments $\sim 2 \%$ of germinated spores) differentiated a haustorial mother cell and a haustorium within $1-2$ days after inoculation.

Under these conditions, no further development of the rust fungus occurred except in a few cases $(<0.3 \%)$, where a second haustorium was formed.

In the next experiments, the tap water was replaced by solutions of distilled water with $1 \%$ sucrose or $1 \%$ sucrose with $0.1 \%$ Wuxal (a commercial 

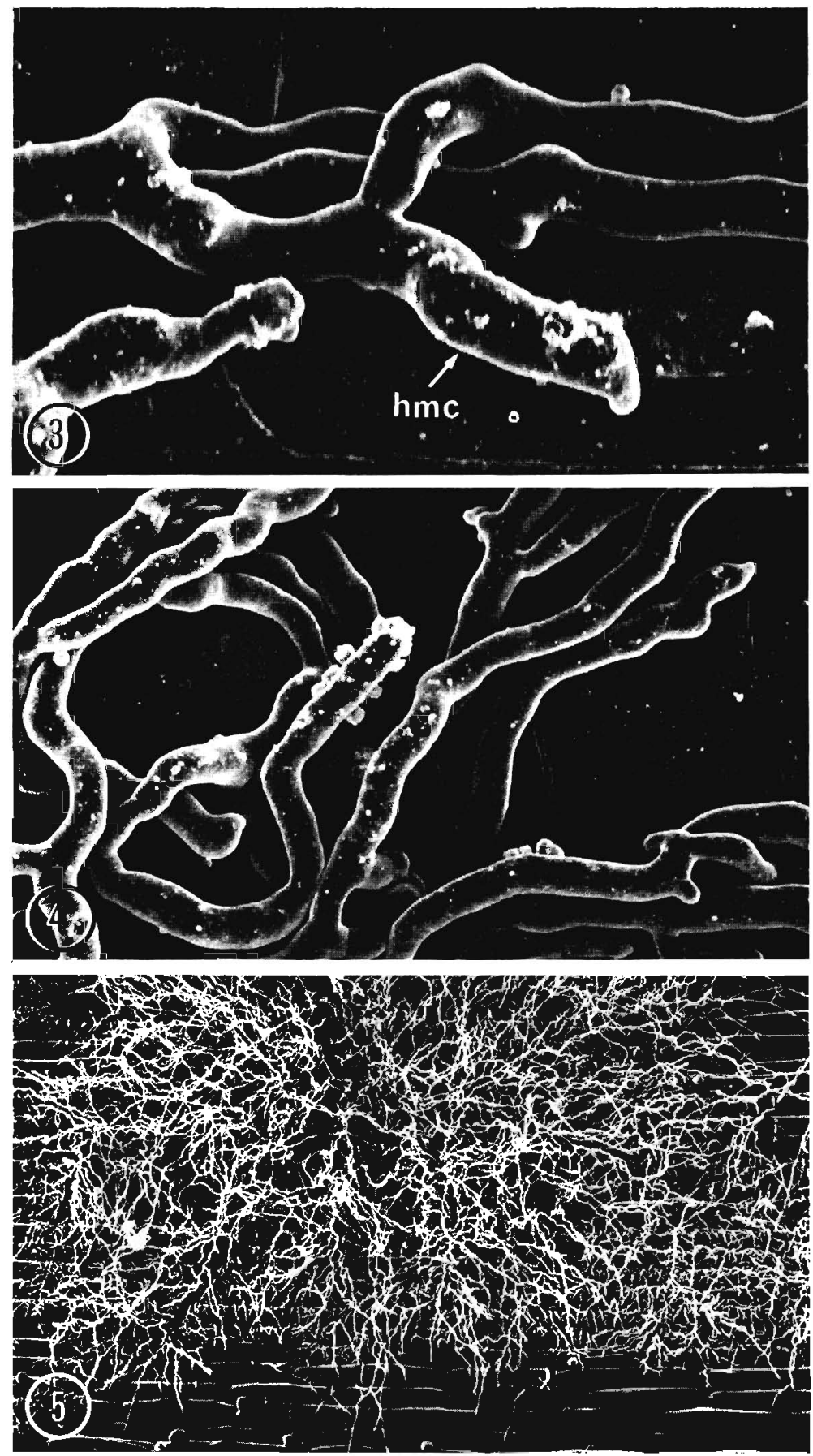

Fig. 3. SEM of hyphae, showing hyphal branching and the haustorial mother cell $(\times 2500)$. Fig. 4. SEM of hyphal development $(\times 1000)$. - Fig. 5. SEM of the mycelium, 8 days after inoculation, on the inner epidermis $(\times 60)$ 
fertilizer produced by Schering AG, Berlin). When the cultures were incubated on these solutions the number of appressoria and substomatal vesicles did not change, the number of infection hyphae with a haustorial mother cell increased only slightly $(\sim 3 \%$ in 10 experiments with $\sim 300$ sporelings each). But nearly all sporelings with a haustorial mother cell developed a haustorium, branched and formed more haustorial mother cells (Fig. 3, 4) with haustoria. Small colonies developed (Fig. 5) and uredospores were formed between 8 and 20 days after inoculation (Figs. 6,7). Uredospore formation was sporadic. It was observed regularly during summer, but seldom during winter. The uredospores caused normal infections when spayed on susceptible cultivars.

To study the effect of different carbohydrates on the growth of the rust fungus, the diameter of the colonies was measured eight days after inoculation. The colony diameter was $4.5 \pm 1.5 \mathrm{~mm}$ with $1 \%$ sucrose, $6.5 \pm 1.5 \mathrm{~mm}$ whith $1 \% \mathrm{D}(+)$ glucose (Merck, Darmstadt), $2.5 \pm 0.9 \mathrm{~mm}$ with D-mannitol. No growth took place with $1 \% \mathrm{D}$-galactose and $1 \% \mathrm{~L}$-arabinose (all other sugars from Serva, Heidelberg).

When the sporelings did not form haustoria, the epidermal cells died after a week or two, as observed by cytoplasmic streaming. Epidermal areas with rust colonies and haustoria (sometimes 200 haustoria per colony and up to 6 haustoria per cell) lived about one month. In such cultures, microbial contamination was washed away with the indicated solutions every two days.

\section{Cytology of the mycelium and the haustoria}

Most hyphae were growing in close contact with the cell surface in young cultures (Fig. 3). They had a typical growth pattern: stopping of hyphal tip
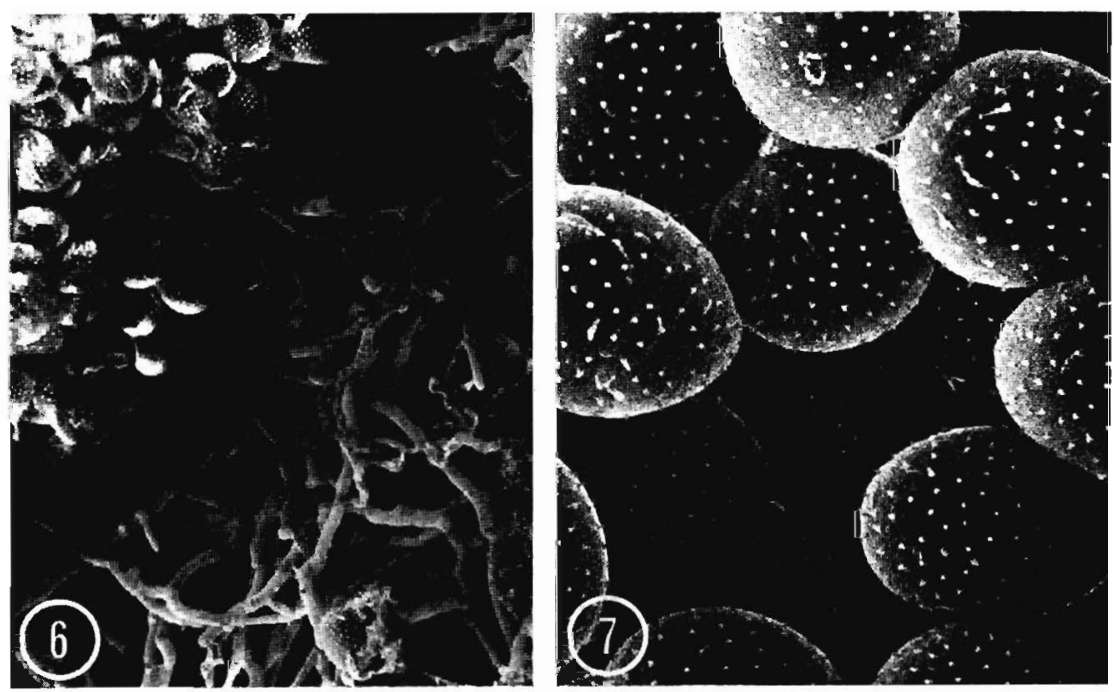

Fig. 6. SEM of uredospores developed by the mycelium about 18 days after inoculation $(\times 150)$. - Fig. 7. SEM of uredospores, about 12 days after inoculation $(\times 1000)$ 

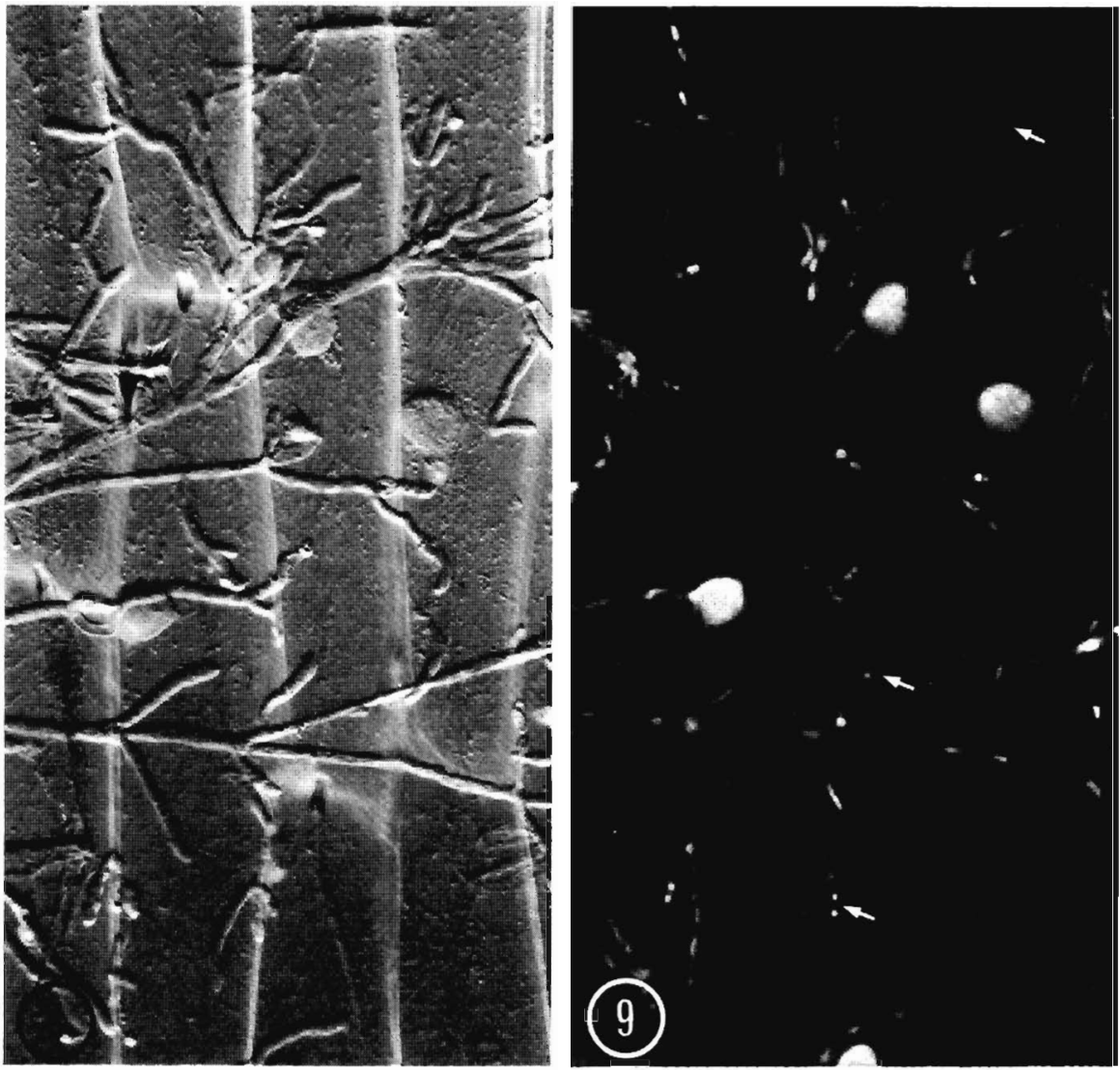

Fig. 8. Hyphal development as seen with interference contrast optics, stained with DAPI $(\times 4000)$. - Fig. 9. Same preparation as Figure 9, but this time after exication with blue light in a fluorescence microscope, showing nuclear distribution in hyphae and haustorial mother cells - arrows $(\times 400)$

growth indicated the formation of a haustorial mother cell. Behind the haustorial mother cell septum, branching occurred (Figs. 8, 9). Staining of hyphae with the fluorochrome DAPI showed the nuclei in a bright blue fluorescence after blue light excitation (Fig. 9). Hyphae showed a very even distribution of the coordinated two nuclei within the mycelium (Fig. 9). Close to the haustorial mother cell septum, another two nuclei were observed very often. When the haustorial body was formed and the cytoplasm migrated into the haustorium, the nuclei migrated into the haustorium. Very often one nucleus in the haustorium and one nucleus in the haustorial body were observed. About half of the mature haustoria (with an empty haustorial mother cell) seemed to contain only one nucleus. Since all haustorial mother cells observed had two, generally condensed nuclei, we were unable to determine whether in mature haustoria, the two nuclei had fused, were in close contact or whether one nucleus had deteriorated. 
The fine structure of hyphae corresponded to observations in normal leaf infections except that slime was observed at many contact sites between hyphae and the host cells and hyphae (Figs. 10 and 11). Also haustoria in the epidermal cells corresponded to haustoria described in normal leaf infections

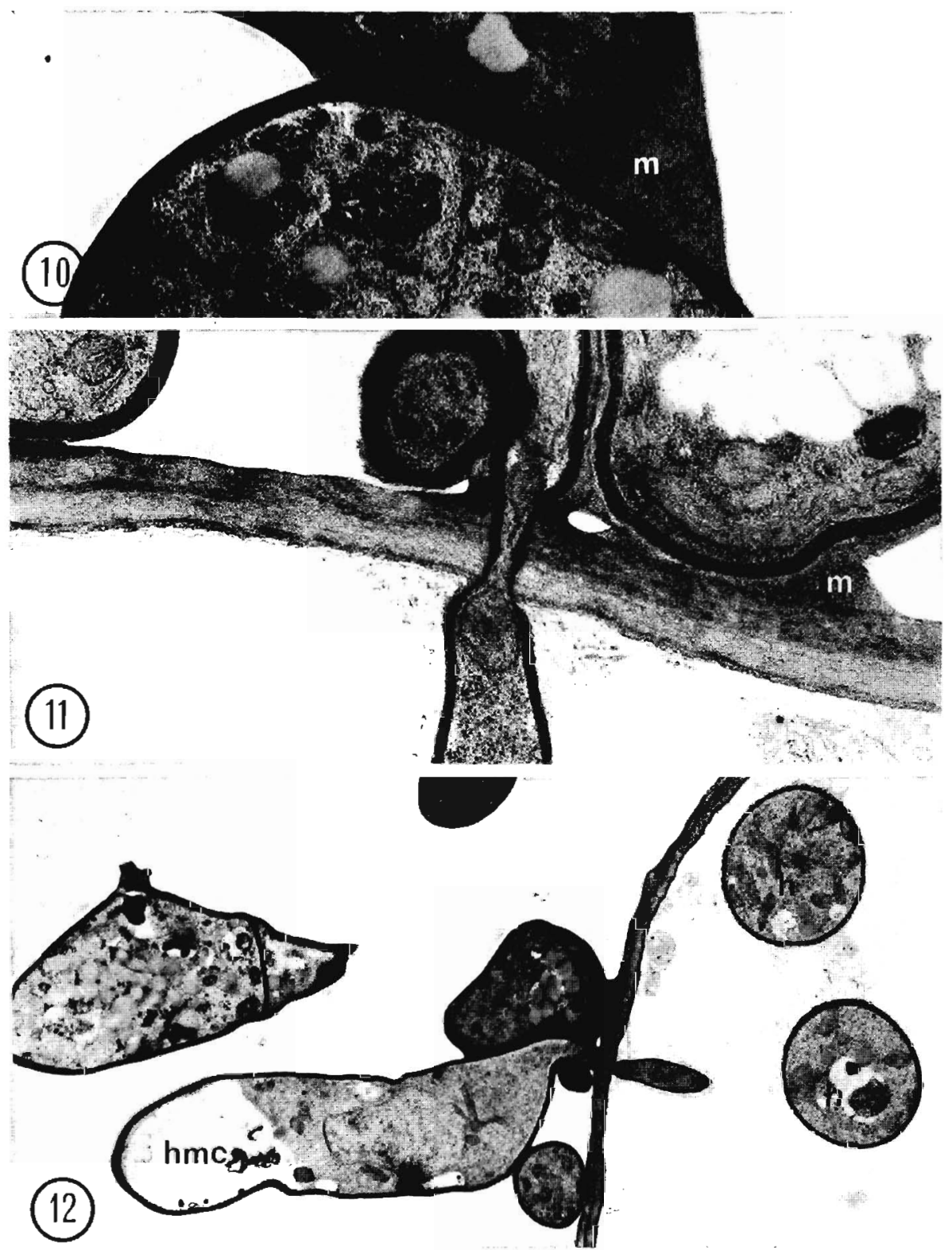

Fig. 10. Transmission electron micrograph showing hyphae and a material (m) like slime between these hyphae $(\times 5400)$. - Fig. 11. Material $(\mathrm{m})$ between hyphae and the epidermal cell $(\times 5400)$. - Fig. 12. Cross section showing hyphae, a haustorial mother cell (hmc) and haustoria $(\mathrm{h})(\times 2800)$ 
(see Littlefield and Heath 1979, Harder and Chong 1984). The penetration peg of the haustorial mother cell was regularly at the tip of that cell (Fig. 12).

\section{Discussion}

A number of biotrophic parasites can be grown in callus tissue or in organ cultures (see INGRAM 1976). For some rusts, the combination of dead host tissue and a culture medium provided a more suitable environment for growth and sporulation than a culture medium alone (INGRAM and TOMMERUP 1973). The rust culture described here uses a dissected cell layer from the differentiated coleoptile which has finished growth. The cell layer, the inner epidermis of the coleoptile, must be fed with sugars to sustain fungal growth. But growth occurs only on the inner surface of the epidermis (Mendgen 1982).

In contrast to observations with other rusts in axenic culture (Grambow and Müller 1978, KuсK 1979, see Maclean 1982), formation of infection structures was a precondition for fungal growth on the cell monolayer. This corresponds with earlier observations with rust cultures (see WiLliams 1982) and with uredospores of $P$. graminis which were deposited in dissected leaves (Chakravarti 1966). Kuck (1979) observed that mycelia developed much earlier when infection structure formation was induced, but once fungal growth was initiated, further development of the mycelium was independent of events in the initial stages. Obviously, complex recognition phenomena during formation of infection structures are important for a normal development of a rust colony (MENDGEN 1982).

In contrast to undifferentiated outgrowth in axenic cultures (WILLIams 1969, Foudin and WYNN 1972), haustoria with a haustorial mother cell, a haustorial neck and a haustorial body are formed. The differentiation of these structures seems to follow the normal way as described in the leaf. Also the fine structure of the haustorium mainly corresponds to earlier fine structural studies in crown rust infected oat leaves except for the deposition of slime between some hyphae and the host surface and the hyphae (see HARDER and ChONG 1984).

Nuclear migration and nuclear behavior is also accessible to observation. Our studies confirm earlier results derived from sectioned material (see HARDER and CHONG 1984).

Preliminary studies on the nutritional needs of the infected epidermis indicate that optimal growth can be obtained with glucose as carbohydrate. Sucrose, and to a lesser extent mannitol, also allow fungal growth. But not D-galactose and L-arabinose. Similar results were obtained with axenic culture of Puccinia graminis (see MACLEAN 1982). It remains to be shown whether the sugars in our culture reached the fungus via diffusion from the surface of the cell or via the haustoria and the cytoplasm of the host. Under natural conditions, the metabolite concentration is higher in haustoria and implies a flow from the haustorium into the rust mycelium (MENDGEN 1981). 
The main problem we still have to solve is the low rate of success (only $2-3 \%$ of germ tubes form colonies) and the microbial contamination. Development of a contaminant free culture is in progress using sterile coleoptiles and sterile uredospores.

We thank Prof. Bardele and Horst Schoppmann, both University Tübingen, Dr. D. Kuscheck (Kontron) and Dr. W. Hert, both München, for help with the scanning electron microscopes and the cryo transfer systems. Dr. P. G. Williams kindly read the manuscript. A grant from the Deutsche Forschungsgemeinschaft (Me 523/9) is greatly acknowledged.

\section{Literature}

Bushnell, W. R., J. Dueck, and J. B. Rowell, 1977: Living haustoria and hyphae of Erysiphe graminis f.sp. bordei with intact and partly dissected host cells of Hordeum vulgare. Canad. J. Bot. 45, 1719-1732.

Chakravarti, B. P., 1966: Attempts to alter infection processes and aggressiveness of Puccinia graminis var. tritici. Phytopathology 56, 223-229.

Foudin, A. S., and W. K. WYNN, 1972: Growth of Puccinia graminis f. sp. tritici on a defined medium. Phytopathology 62,1032-1040.

Grambow, H. J., and D. Müller, 1978: Nuclear condition, types of hyphal development from differentiating and nondifferentiating uredosporelings, and effect of 3,3'-bis- indolmethone on Puccinia graminis f. sp. tritici in vitro. Canad. J. Bot. 56, 736-741.

Harder, D., and J. Chong, 1984 : Structure and physiology of haustoria. In: W. R. Bushneli and A. P. Roelfs (Eds.), The cereal rusts. Academic Press, New York.

Hotson, H. H., and V. M. CUtTeR, Jr., 1951: The isolation and culture of Gymnosporangium juniperi-virginianae Schw. upon artificial media. Proc. Nat. Acad. Sci. U.S.A. 37, $400-403$.

InGRAm, D. S., and I. C. Tommerup, 1973: The study of obligate parasites in vitro. In: R. J. W. Byrde and C. V. Cutting (Eds.), Fungal pathogenicity and the plant's response. Academic Press, New York.

- -, 1976: Growth of biotrophic parasites in tissue culture. In: R. Heitefuss and P. H. Williams (Eds.), Physiological plant pathology. Springer Verlag, Berlin - Heidelberg.

KUск, K. H., 1979: Über die infektionsbedingten Veränderungen der Aminosäuren und Fettsäuren in mit Puccinia graminis f. sp. tritici, Rasse 32, infizierten Weizenblättern und die in vitro-Sporulation des Pilzes. Dissertation Aachen 1979.

Littlefield, L. J., and M. C. Heath, 1979: Ultrastructure of rust fungi. Academic Press, London and New York.

Maclean, D. J., 1982: Axenic culture and metabolism of rust fungi. In: K. J. Scott and A. K. Chakravorty (Eds.), The rust fungi, 37-120. Academic Press, London and New York.

Mendgen, K., 1981: Nutrient uptake in rust fungi. Phytopathology 9, 983-989.

- - 1982: Differential recognition of the outer and inner walls of epidermal cells by a rust fungus. Naturwissenschaften 69, 502-503.

Takamatsu, S., H. Ishizaki, and H. KunOH, 1978: Cytological studies of early stages of powdery mildew in barley and wheat. V. Effects of calcium on the infeotion of coleoptiles of barley by Erysiphe graminis hordei. Canad. J. Bot. 56, 2544-2549.

Williams, P. G., 1969: Haustoria-like branches in axenic cultures of Puccinia graminis f.sp. tritici. Canad. J. Bot. 47, 1816-1817.

- -, 1984: Obligate parasitism and axenic culture. In: W. R. Bushnell and A. P. Roelfs (Eds.), The cereal rusts. Academic Press, New York.

- -, K. J. Scott, and J. L. Kunl, 1966: Vegetative growth of Puccinia graminis f. sp. tritici in vitro. Phytopathology 56, 1418-1419.

Author's address: Prof. Dr. Kurt Mendgen, Universität Konstanz, Fakultät für Biologie, Lehrstuhl Phytopathologie, D-7750 Konstanz (F.R. Germany). 